\title{
The Constantinian Bronze Colossus Nero's Hairstyle and the Beard of Commodus
}

\begin{abstract}
The colossal Constantinian bronze portrait in the Capitoline Museum stands out as a unique example of Roman, large-scale portraiture. It is a rare bronze portrait of colossal size, which included a lot of material of a kind which was usually remoulded into exchangeable goods in Late Antiquity. It was constructed from separately cast parts, and with a close look, there are traces of retouching and alterations. The reuse was undertaken by way of highly skilled refashioning techniques. In the present paper, I venture to suggest that the bronze colossus originally portrayed Nero (AD 54-68), thereafter Commodus (AD 177-192), before it was given its present appearance in the early fourth century.
\end{abstract}

\section{Introduction}

The bronze colossus of Constantine (AD 306-337) or one of his sons, which is exhibited in the Capitoline Museums, is known to have been standing outside the Lateran in the Middle Ages (FIG. 1a-c). ${ }^{1}$ It belonged to a statue of colossal dimensions, the head alone measuring $1.77 \mathrm{~m}$. It is comparable only to the colossal marble head from the Basilica of Maxentius, also in the Capitoline Museums, in the cortile (FIG. 2a-b). ${ }^{2}$ The bronze colossus is often mentioned alongside the one of marble, since these heads, irrespective of the difference in size the marble one being the taller - are the largest surviving colossi from Roman times. What made exactly these two survive, from a large number of large-scale portrait statues? Probably for the same reason why the equestrian statue of Marcus Aurelius escaped the melting-pot: They were believed to represent Constantine as the first Christian emperor. Later research

\footnotetext{
${ }^{1}$ Ensoli 2000, 78-81 with an overview of the medieval sources. See also Ruck 2007, 248-249. Benjamin of Tudela (ed. 1993, 11) mentioned a colossus in front of the Lateran in the twelfth century, which he referred to as "Samson" and which Ensoli discusses in relation to the bronze colossus. Benjamin informs, however, that this colossus was made of marble. Nevertheless, Ensoli's point is that the colossus mentioned by Benjamin may be the same as the one in the drawing by Paolino da Venezia in the 1320's. The colossus in the drawing could be the bronze colossus. See also the Codice Topografico 1940-1953, 149.

${ }^{2}$ Fittschen, Zanker 1985, 152-155 no. 123. The Museo della Civiltà Romana posseses a plaster cast.
} 

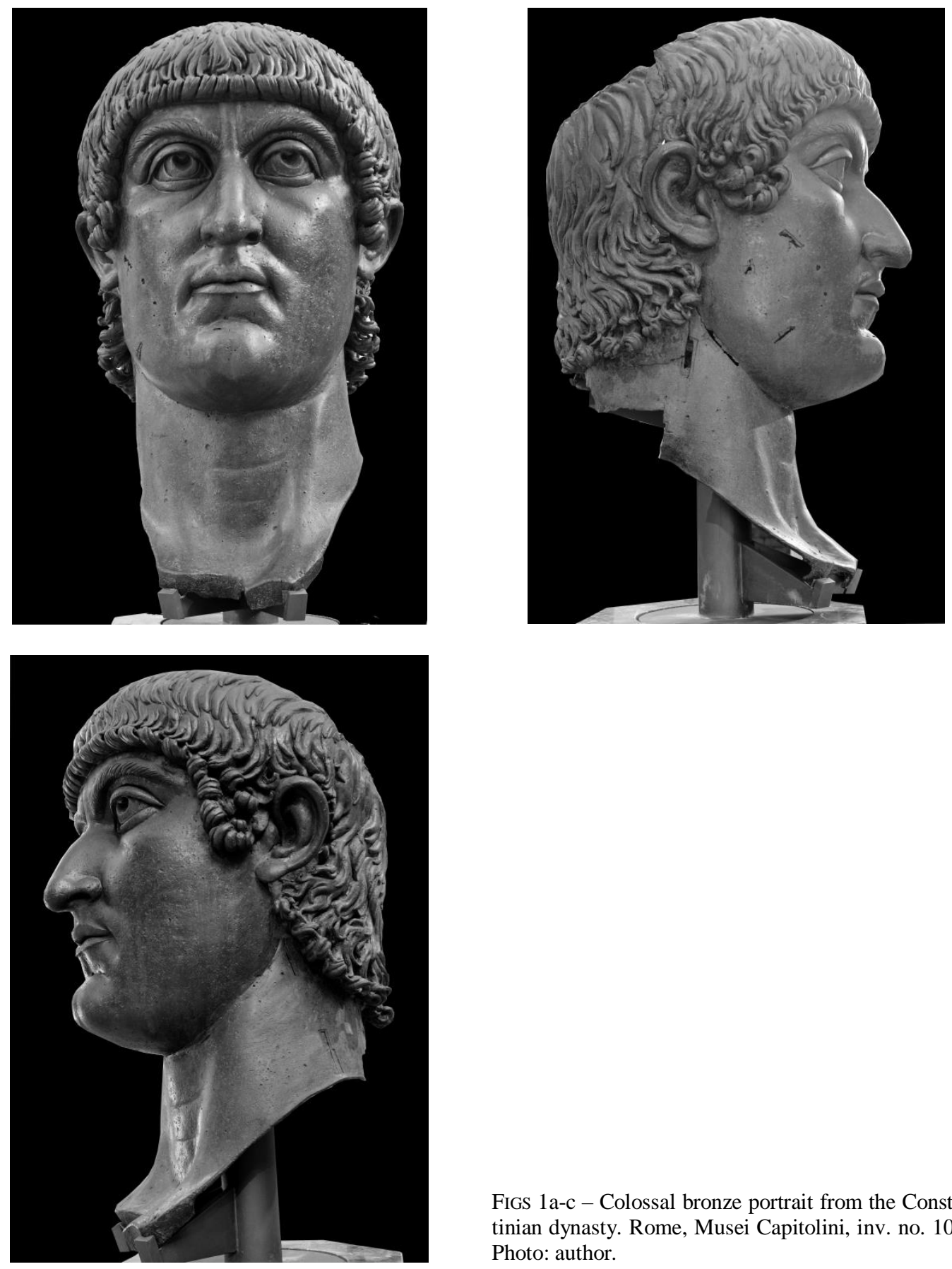

FIGS 1a-c - Colossal bronze portrait from the Constantinian dynasty. Rome, Musei Capitolini, inv. no. 1072. Photo: author. 

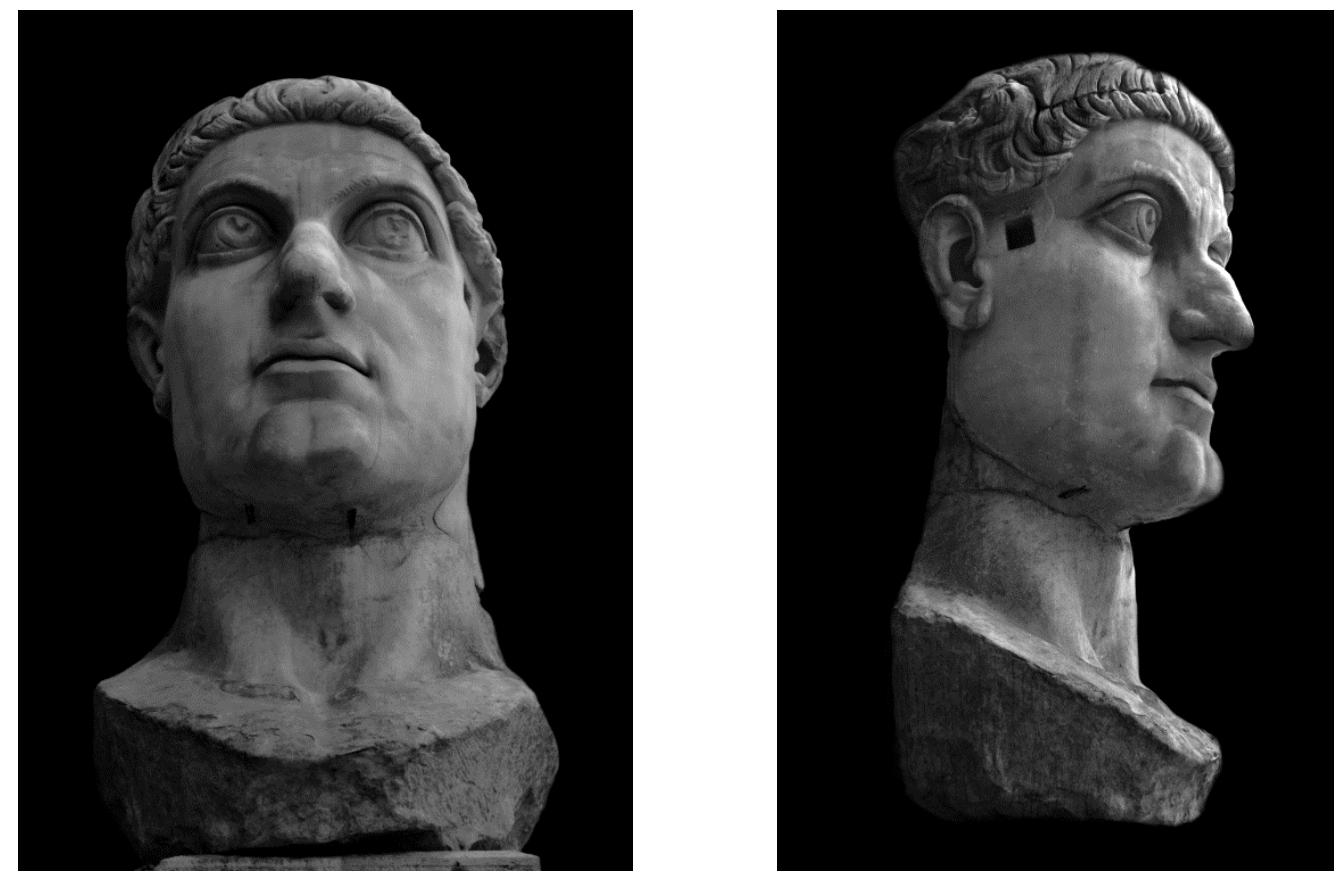

FIGs 2a-b - Colossal marble portrait of Constantine. Rome, Musei Capitolini, inv. no. 1622. Photo: author.

has, however, demonstrated that the marble colossus originally showed Hadrian, and was recut into Constantine in Late Antiquity, when almost all marble sculptures were reused or burnt to lime. ${ }^{3}$ In the following, I would like to suggest that the bronze colossus was also reused, that it originally showed Nero, after which it was reused as Commodus, ${ }^{4}$ and then again in Late Antiquity, it was given the identity of a Constantinian emperor.

In Late Antiquity, earlier colossi such as Nero's gigantic bronze statue of Helios and a large number of cult statues of deified emperors from the $1^{\text {st }}$ and $2^{\text {nd }}$ centuries were still present in the urban landscape. ${ }^{5}$ Monumental works of art could be employed successfully as a part of ruler strategies, and their potential as such in ancient Rome has been the subject of numerous studies, often based on the use of spolia on the Arch of Constantine. Since the 1930's, the spolia on the Arch have been regarded as a connection between Constantine's ruler ideology and those of the "good" emperors of the second century, through a retrospective sculpture programme. ${ }^{6}$ The same can be said about the colossal marble portrait of Constantine, which was probably an acrolith, composed by parts which could be detached and remounted. ${ }^{7}$ The location of the original acrolith is unknown, like that of the bronze colossus. While the other reused sculpture at the time of Constantine had a retrospective element, this

\footnotetext{
${ }^{3}$ Evers 1991. For more recent literature on the reuse of portraits, see Varner 2004; 2010; Prusac 2011.

${ }^{4}$ This hypothesis was given by Flavio Biondo in 1481, see Ensoli 2000, 81.

${ }^{5}$ For Nero's colossus of Helios, see Suet. Nero 31; Plin. NH 34,41 and 75; Cass. Dio 65,15,1. See also Kreikenbom 1992, 95-96; Ensoli 2000, 82-84; Ruck 2007, 170-172.

${ }^{6}$ L'Orange, von Gerkan 1939.

${ }^{7}$ Parisi Presicce 2006.
} 

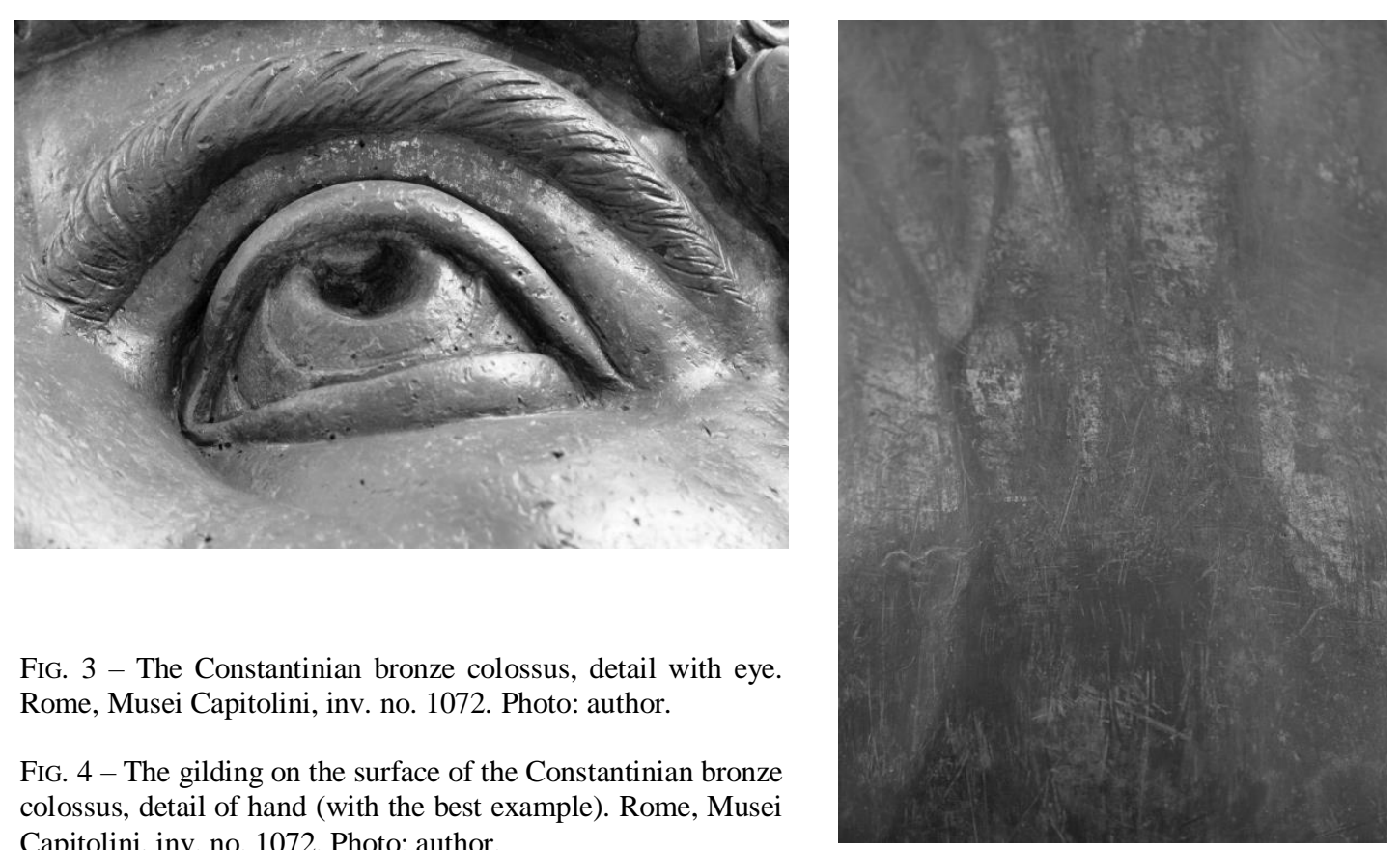

FIG. 3 - The Constantinian bronze colossus, detail with eye. Rome, Musei Capitolini, inv. no. 1072. Photo: author.

FIG. 4 - The gilding on the surface of the Constantinian bronze colossus, detail of hand (with the best example). Rome, Musei Capitolini, inv. no. 1072. Photo: author.

does not seem to be the case with the bronze colossus. ${ }^{8}$ That is, at least not to Constantine. If it had been intended for reuse by Maxentius (AD 306-312), a harking back to Commodus may have played a role, as I will come back to below.

\section{Description}

The head of the colossal bronze measures $1.25 \mathrm{~m}$ from the chin to the peak of the dome, and is Late Antique in style, with sharp features and clearly pronounced eyes (FIG. 3). It is composed by different, separately moulded parts, which could be refashioned. ${ }^{9}$ The different parts have been joined together irregularly, some parts have been analysed and show at least two different alloys: 1) The face, the front hair and the ears; 2) the back of the coiffure and the neck; 3) the front of the neck. The top of the head is missing. The surface has remains of gilding, which reveal that the head once was golden and shining (FIG. 4). But, seen from a closeup angle, the surface of the sculpture is full of small scars, due to air bubbles in the casting process (FIGS 3 and 5). According to a medieval source, it had a radiate crown, a corona auream gemmis ornatam, an arm with a globe and a hand which held a sword. ${ }^{10}$ One hand and the globe have survived (FIG. 6). There is no trace of the attachments of the radiate crown, which is a typical attribute for the sun god, and which may be the corona aurea mentioned

\footnotetext{
${ }^{8}$ Liverani 2004 argues that there was no ideology behind the reuse of spolia on the Arch of Constantine. He suggests that spolia were used for practical or even arbitrary reasons. Some of the questions concerning the reused reliefs on the Arch are relevant to the understanding of the reused public sculpture. In Prusac 2012 I have confronted Liverani's hypothesis and argued, on the basis of memory theory, that the identity of public art had a strong foothold among the population, and was not easily forgot ten.

${ }^{9}$ Fittschen, Zanker 1985, 153.

${ }^{10}$ Ensoli 2000, 80-81.
} 
FIG. 5 - Close-up of the upper part of the face of the Constantinian bronze colossus showing airbubbles in the bronze. Rome, Musei Capitolini, inv. no. 1072. Photo: author.

FIG. 6 - The bronze colossus with the hand and the globe as displayed. Rome, Musei Capitolini, inv. no. 1072. Photo: author.

FIG. 7 - The inside of the Constantinian bronze colossus. Rome, Musei Capitolini, inv. 1072. Photo: author.

in the medieval source. ${ }^{11}$ Birgitte Ruck, in her work on Imperial Roman colossi, declares like S. Ensoli that such remains cannot be identified. ${ }^{12}$ Since the rest of the head is composed of different parts and the top of the head is missing, it is, however, plausible that there was a diadem or a crown on the head of the bronze colossus. Such an attribute is typical of late-Antique ruler portraits.

On the inside, there is the uneven surface which is typical of the cire perdue casting technique (FIG. 7). The right half of the face is shifted slightly downwards in relation to the left, which may be because of the head's slight turn towards left. ${ }^{13}$ On the left side, the face is slightly more flat. On both sides of the face, the cheekbones are protruding in an angular frame, a feature which Klaus Fittschen and Paul Zanker compare to the Quincennalia-type portrait of Constantine, and there is no reason to question their conclusion, that the characteristics of the bronze colossus seem to have the closest parallel in the Vicennalia-type portrait. ${ }^{14}$
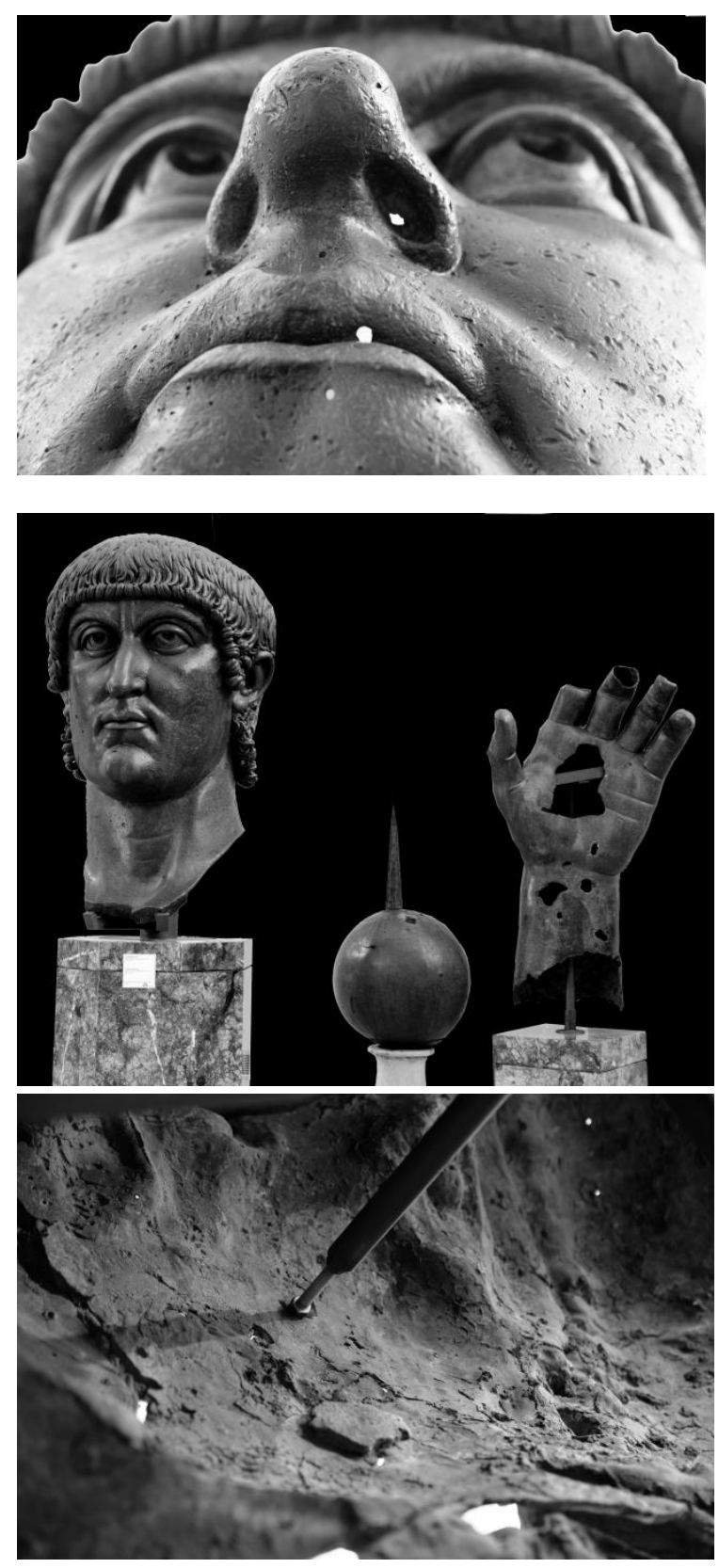

\footnotetext{
${ }^{11}$ Ensoli 2000, 71; Delbrueck 1933, 143; Ruck 2007, 249.

${ }^{12}$ Ensoli 2007, 249.

${ }^{13}$ Fittschen, Zanker 1985, 154.

${ }^{14}$ Fittschen, Zanker 1985, 155.
} 


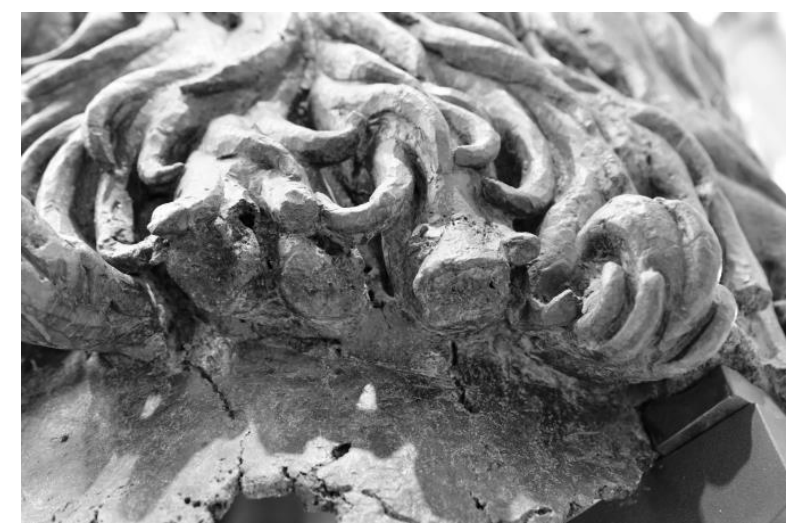

FIG. 8 - Close-up of the hair-locks at the nape of the neck of the Constantinian bronze colossus. Rome, Musei Capitolini, inv. no. 1072. Photo: author.

The face is fleshy and can be claimed to have certain individuality, despite the conventionalized countenance. As it now stands, it is solemn and stern, with eyes looking upwards. The aquiline nose begins at the top with a narrow concavity below the two vertical lines or wrinkles between the eyes. The nose is rather narrow and ends in a downward pointing tip, with symmetric nasolabial lines. The lines beside the nostrils are also symmetric, emphasizing the conventionalized appearance of the face. The wrinkles between the eyes seem to start behind the fringe of hair above the brow, as if they were remains of an earlier portrait, before the present coiffure in front was moulded. The string of curls above the forehead is meticulously executed, and the hair at the back of the head is delicately formed, with each undulating strand of hair carefully defined. At the neck, the lower part of the locks is broken off (FIG. 8). Where the neck ends, we can assume that it was attached to some kind of cloak or garment of unknown material.

Stylistic discrepancies between the face and the hair locks at the back of the head suggest that it was possible to alter the different parts when they were detached. ${ }^{15}$ There are other examples of such operations, such as for example in the case of the equestrian bronze statue of a Roman emperor, which was found in the sea by Misenum, and which originally featured the portrait of Domitian. ${ }^{16}$ Later, after Domitians's damnatio memoriae, the face of the Misenum bronze was removed and remoulded into a new one, of Nerva. In cases with colossal portraiture, however, it might not have been a straightforward task to dismantle and remould the entire head, even if it was composed of different parts. It may have been less complicated to rework the details of the facial features in cold and to add separately moulded parts, in order to alter the already existing portrait. In the famous passage in Pliny the Elder, when he writes statuarum capita permutantur, he may not mean that the heads were always exchanged with new ones, when the portrait statues were reused for new individuals. ${ }^{17}$ "Permutare" can also mean "alter" and "change."

The chin has a juvenile chubbiness, but because of its heaviness it is at the same time emphasizing the stern and authoritative expression of the emperor. There seem to be few portraits of a smaller scale with a similar broad chin, and this may be due to the material, and the need of a balanced weight on the top of a tall statue.

An origin in another portrait would explain the features of the colossal bronze head, which

\footnotetext{
${ }^{15}$ Contra Ruck 2007, 243 note 101.

${ }^{16}$ Macchiaroli 1987, 52; Varner 2004, 114 ca. no. 5.7.

${ }^{17}$ Plin. NH 35.4.
} 
Fittschen and Zanker considered as not Constantinian, but which, in their opinion, was caused by the adjustments which were necessary for portraits which were to be viewed from below:

“(...) z. B. in den Falten unter den Augen und um den Mund, in der scharf abgegrenzten und in der Mitte unterteilten Kinnspitze. Die schmalere und langgezogene Gesamtform gleicht sich indes in der Ansicht von unten aus. Die flachen, knochigen Wangen entsprechen durchaus der Physiognomie, die der getreuen Repliken des Quinquennalien-Typus überliefern (...). Da $\beta$ das Faltensystem auf eine sehr viel schmalere Fläche zusammengedrängt ist, hängt mit dem andersartigen plastischen Aufbau des Kopfes zusammen und ist ebenso wie die Vergrößerung und Betonung der Brauenbögen und der schmalere Nasenrücken durch den veränderten Stil bzws. Ausdruckswillen bedingt. Die physiognomischen Charakteristika sind also durchaus mit denen der Constantinsbildnisse zu vereinbaren." “18

The irregularities may purportedly have been made by the artists, who paid attention to the fact that the head was to be viewed from below, and had to be adjusted according to the perspective of the viewer. This explanation would also be valid for a colossal portrait of Nero, and for that matter, of Commodus. Usually, colossi have enlarged eyes, since they were regarded from below. The sightlines would otherwise make the face look too small. Most surviving colossal portraits are made of marble and are not always suited for comparison to bronzes, and the material makes them different. Furthermore, there is a difference in size between bronze colossi and miniature art made of metals, such as coin images. Colossal and miniature art differ, since the production of them required different methods. The irregularities in the portrait of Constantine may also have been caused by the several different parts from which it was made, and the necessity of making them fit to each other. When the parts were cast separately, it might have been difficult to join them in a way which resulted in more 'natural' proportions.

\section{Dating and attribution}

Based on coin images, Serena Ensoli suggests AD 326 as the latest possible date for the bronze colossus in its present form. ${ }^{19}$ Earlier scholars, such as Richard Delbrück and Hans Peter L'Orange, have argued for a later date, however, suggesting that the bronze colossus shows one of Constantine's sons. ${ }^{20}$ Fittschen and Zanker, as we have seen above, suggest that it could represent Constantine, as they compare it to the Vicennalia-type portrait on coins.

The images supposedly attributed to Constantius II differ from each other, and it is difficult to ascertain whether or not they represent the same individual. The colossal marble portrait which is attributed to Constantius II in the Musei Capitolini is, for instance, not similar

\footnotetext{
${ }^{18}$ Fittschen, Zanker 1985, 154.

${ }^{19}$ Ensoli 2000, 78.

${ }^{20}$ Delbrück 1933, 139-144, pls 52-54, figs 39-41; L'Orange 1933, 64, 138 no. 87, figs 64 and 164; Ensoli 2000, 77-78. Delbrück and L'Orange attributed the colossal bronze portrait to Constantius II; Heinz Kähler (1952, 22-24 note 67) identified it as Constantine; Fittschen and Zanker (1985, 152-153) suggest a late Constantinian date.
} 

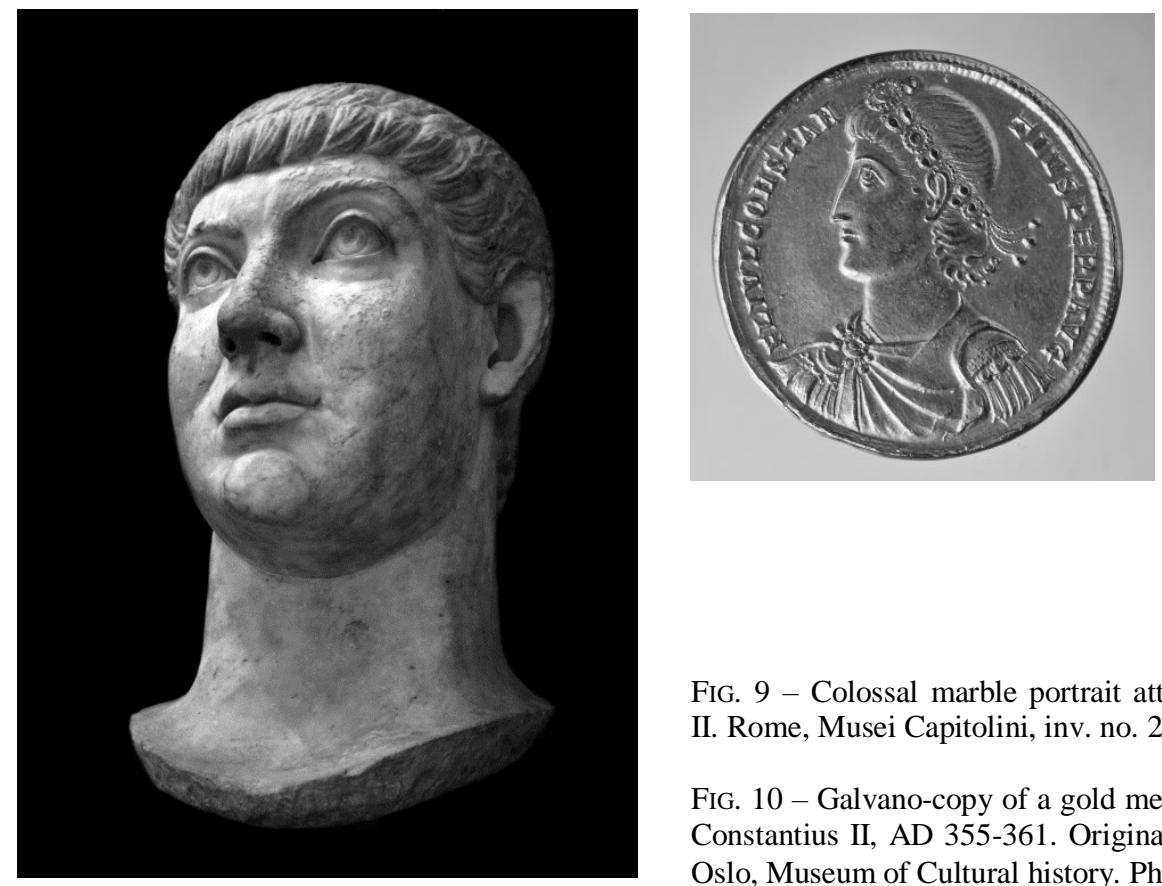

FIG. 9 - Colossal marble portrait attributed to Constantius II. Rome, Musei Capitolini, inv. no. 2882. Photo: author.

FIG. 10 - Galvano-copy of a gold medal with the portrait of Constantius II, AD 355-361. Originally minted in Antioch. Oslo, Museum of Cultural history. Photo: Håkon Roland.

to the bronze colossus (FIG. 9). The facial features of the bronze colossus are, however, close to some coin images of Constantius II, as seen for example in a gold medal with his portrait from Antioch, from AD 355-361 (FIG. 10). The features are closer to the coin images of Constantius II than to those of Constantine, but there is also a strong similarity to the latter, especially with regard to the nose. ${ }^{21}$ A good example is a copper-coin from Arles, from AD 327 (FIG. 11).

The presence of a colossal portrait statue of Constantine in Rome appears more likely than one of Constantius II, who visited the city only once. Yet, Constantius II's visit was celebrated with the erection of statues of which the bronze colossus could be an example. At the occasion of Constantius II's visit to Rome, so vividly documented by Ammianus Marcellinus, two large-scale bases with inscriptions from the Forum Romanum indicate that at least two statues of larger than life-size were erected - or relocated and re-dedicated - in his honour. ${ }^{22}$ Unfortunately one of the inscriptions is badly preserved, but the other one can be read without difficulties. ${ }^{23}$

\footnotetext{
${ }^{21}$ The aureus from Antioch with an image of Constantius II is RIC VIII.

${ }^{22}$ Amm. Marc. 16, 10, 13-16.

${ }^{23}$ CIL 6, 31395: Propagatori imperii / Romani d(omino) n(ostro) / Fl(avio) Iul(io) Constantino maximo / toto orbe victori ac / triumfatori semper Aug(usto) / Memmius Vitrasius Orfitus v(ir) c(larissimus) / iterum praef(ectus) urbi iud(ex) sac(rarum) cogn(itionum) / tertium d(evotus) n(umini) m(aiestati)q(ue) eius;

[Propagatori? Imperii?] / Romani? d(omino)? n(ostro)?] / [Fl(avio)? Iul(io)? Constantio? maximo?] / [toto? orbe? victori? ac?] / triumfatori? semper? Aug(usto)?] / [Memmius? Vitrasius? Orfi?]tus [v(ir)? c(larissimus)?] / [iterum? praef(ectus)? urbi? iud(ex)? sac(rarum)?] co[gn(itionum)?] / [tertium? d(evotus)? n(umini)? m(aiestati)q(ue)? eius?]

Translated by Humphries 2003, 27-46.
} 

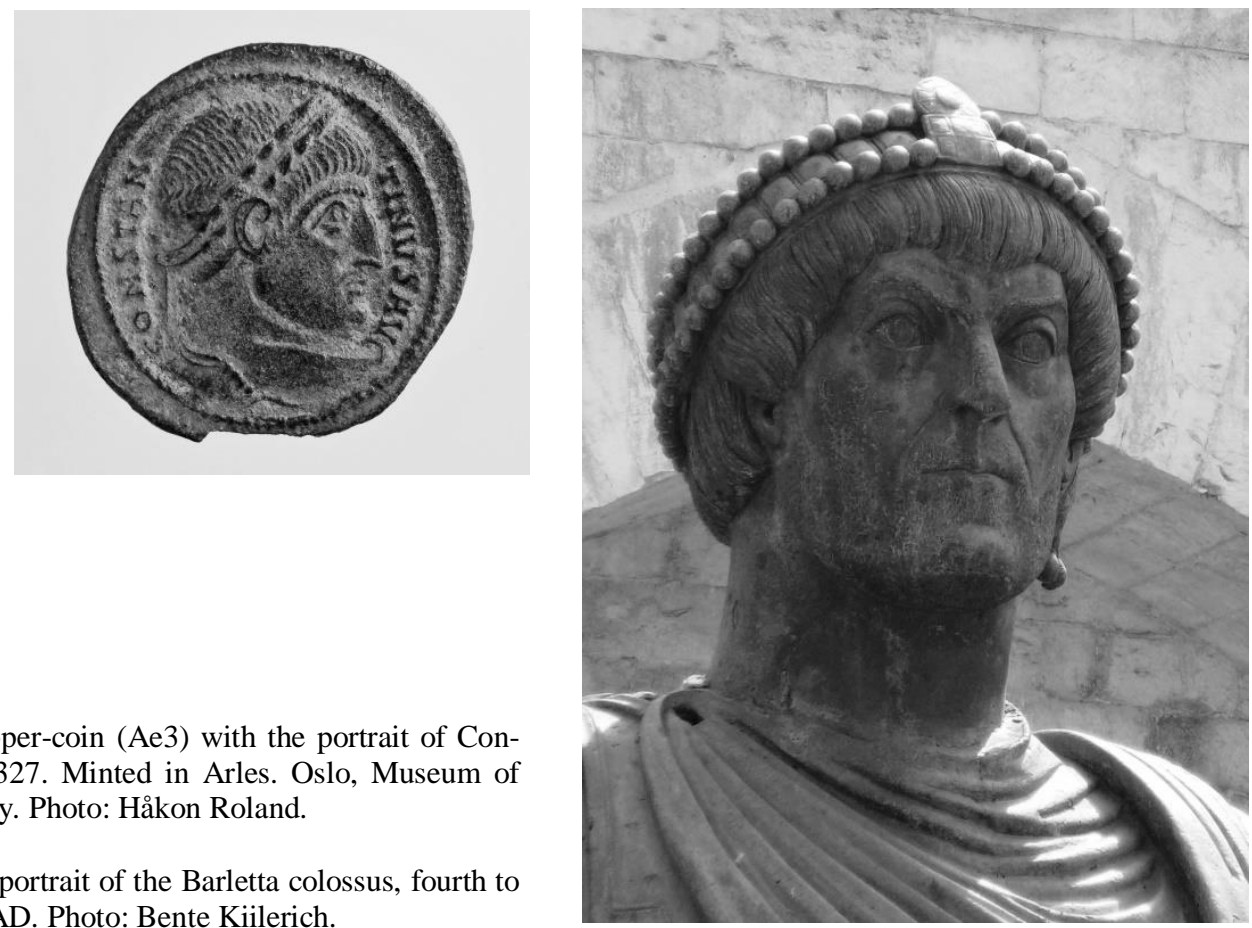

FIG. 11 - Copper-coin (Ae3) with the portrait of Constantine, AD 327. Minted in Arles. Oslo, Museum of Cultural history. Photo: Håkon Roland.

FIG. 12 - The portrait of the Barletta colossus, fourth to sixth century AD. Photo: Bente Kiilerich.

The comparisons to the Barletta colossus should also be mentioned (FIG. 12). The height of the Barletta colossus is $5.11 \mathrm{~m}$., and the head, with the part above the diadem missing, could be roughly estimated to $c 70 \mathrm{~cm}$, which would be approximately half the size of the Constantinian colossus. ${ }^{24}$ Traditionally, the Barletta colossus has been addressed as a possible Heraclius, but recently, thermoluminesence analyses of the clay from the inside of the bronze have resulted in a new dating to between the fourth and the sixth century. ${ }^{25}$ When the Constantinian bronze colossus is compared to the Barletta colossus, the unusual countenance of the first becomes clear. The Barletta colossus seems to follow the schemata of late antique portraiture better than the Constantinian bronze. Perhaps the reason for this is that the Constantinian bronze has been subject to several alterations through time, from the time when it was first made and until it was given the present appearance. Its origin may have been in a portrait of Nero.

\footnotetext{
'To the extender of the Roman empire, our lord Flavius Iulius Constantius, the greatest, victor over the whole world and triumphant, forever Augustus. Memmius Vitrasius Orfitus, of clarissimus rank, prefect of the City for the second time, judge in the imperial court of appeal for the third time, devoted to his divine spirit and majesty, [set this up].'

The inscription celebrates the emperor Constantius II as victorious and triumphant over the whole world, in a reference to his victory over Magnentius. The title toto orbe victor ac triumfator is very close to totius orbis dominus, which according to Ammianus Marcellinus (15.1.3) Constantius liked to use for himself (Humphries 2003, 39-40). See LSA-1360 (C. Machado).

${ }^{24}$ Kiilerich 2015, 55 .

${ }^{25}$ Castellotti 2017, 38. The analyses were undertaken by Emanuela Sibilia at the Laboratorio di Archeometria dell'Università di Milano Bicocca. I am grateful to Siri Sande who directed my attention to the results of the analysis.
} 


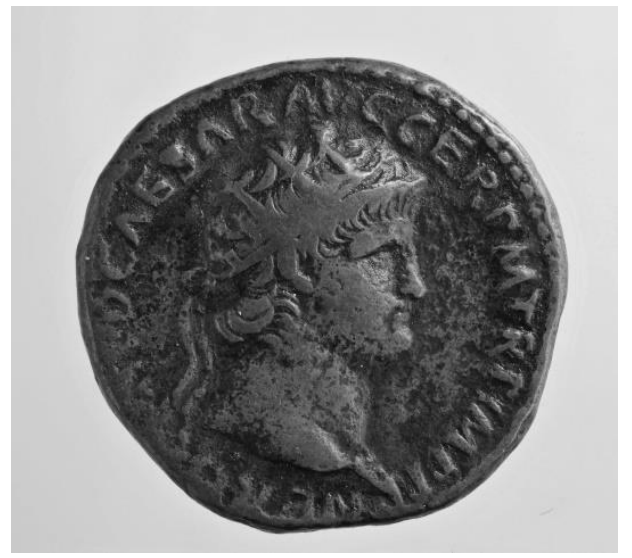

FIG. 13 - Dupondius with the portrait of Nero, AD 64-66. Minted in Rome. Oslo, Museum of Cultural history. Photo: Håkon Roland.

\section{Nero and the original portrait}

One of the most thorough investigations of the history of the bronze colossus is that of Ensoli, who discusses whether it could be a possible version of Nero's sun colossus. ${ }^{26}$ Interestingly, in terms of portrait reuse, Ensoli demonstrates that the Constantinian bronze colossus shows similarities to Julio-Claudian portraiture. ${ }^{27}$ Based on that, she argues that it could originally have been Nero's sun colossus, but because of the size, her interpretation is not convincing.

Ensoli has treated the bronze colossus in several works, in the year 2000, 2002 and 2007. She also refers to a contribution delivered at a congress in 2003 which has apparently never been published, ${ }^{28}$ but the gist of it may be inferred from her latest contribution. Ensoli's hypothesis, which was hinted at in 2000, appears fully developed in 2002 and especially in 2007. According to her, the bronze colossus is identical to that of Nero, though the latter was

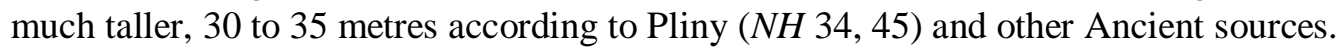

Ensoli tries to neutralize the difference in height by postulating a high base carried by columns for Nero's colossus. ${ }^{29}$ Into this base she incorporates the Hadrianic roundels which now decorate the Arch of Constantine. ${ }^{30}$ They were allegedly added when Hadrian had the colossus removed from the Velia. There is, however, no evidence for this set-up.

There is no secure evidence for the provenance of the Capitoline bronze colossus either. The sources which claim that it came from the Colosseum area are Medieval, and no more reliable than the legends telling that the colossus was destroyed by Pope Gregory the Great (or Pope Sylvester). The statue could also have been erected in the area where its remains were put on display, that is, the Lateran. Before the battle of the Mulvian Bridge in 312, the Lateran area was the site of the Castrum of the Equites Singulares, who fought and perished with Maxentius. Constantine may have wanted to make his presence felt through the erection of an imposing statue. Though the castrum had been razed to the ground and overlaid by the Lateran Basilica, memories of Constantine's opponents probably lingered.

Because of the waving strands of hair at the back of the head, Ensoli directs the attention to the possibility that the bronze colossus could be a case of reuse, in which the backside of the portrait had been left more or less untouched. In my opinion, it is convincing that the Constantinian bronze colossus is reused, although not from the sun colossus of Nero. The

\footnotetext{
${ }^{26}$ Ensoli 2000, 86-90; 2002; 2007. See also Ruck 2007, 250.

${ }^{27}$ Ensoli 2000, 81-85, in particular page 83, also for illustrations.

${ }^{28}$ Ensoli 2007, 406, n. 1, 418-419.

${ }^{29}$ Ensoli 2002, 115-122; 2007, 410-416, Pls. XI, XII.

${ }^{30}$ Ensoli 2007, 418-420, Pl. .
} 
FIG. 14 - Portrait of Nero. Rome, Antiquario Palatino, inv. 618. Photo: Wikimedia Commons.

hairstyle on the back of the head is close to the Julio-Claudian period, and the length of the hair has its only parallel in the hairstyle of Nero. The hairstyle is composed of long strands of hair, recalling the coiffure of the late Julio-Claudian emperors. The bi-forked locks above the forehead strengthen this argument. At the back of the head, the long, wavy locks are particularly reminiscent of the execution of the delicately shaped locks of Nero, as demonstrated by Ensoli. The JulioClaudian strands of hair at the back of the head have been made with care, and the apparent importance of the backside of the head

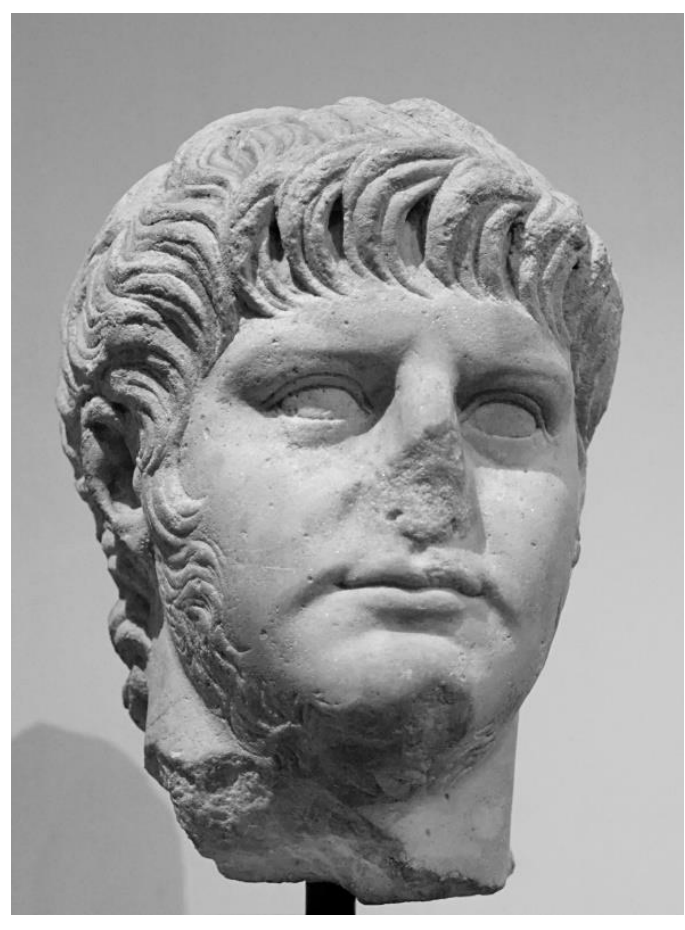
indicates that the colossus was viewed from behind, at least in its original location. The direction of the locks is not identical to that in the known portraits of Nero, but shaped in the same manner, and the length of the hair is approximately the same. It would have been possible to dismantle the back part of the head and remould its lower part. Such a treatment would explain the stylistic discrepancy between the hair at the back of the head and that of the nape of the neck. The edges of the locks have not been smoothed at the nape of the neck, whereas those on the left hand side have survived, and have parallels in the protruding, upturned locks which are present in coin images of Constantine (see FIG. 11, above). Where the locks have survived, they show a successful remoulding of the lower part of the hairstyle of Nero into that of Constantine.

The similarity between the portraits of Nero and the bronze colossus is perhaps easiest to see in profile (FIG. 13). The fleshy lower part of the face corresponds to portraits of Nero, and is at the same time also well suited for Constantine's broad chin. The flabby chin is present in coin images of Nero, which were made contemporaneously with the bronze colossus, but it is mainly the hairstyle which seems to reveal that the head once belonged to him. The long nose of Nero in his coin image is too short when we compare it to that of the bronze colossus. The closely set eyes are present in portraits of Nero, such as for example the famous portrait of him in the Antiquario Palatino, but not enough so as to be counted as a parallel to the colossus (FIG. 14). ${ }^{31}$

The unnaturally low brow, mentioned above, is typical in portraits of Nero, less so in Constantinian portraits, but some images of both emperors sometimes show this facial feature

\footnotetext{
${ }^{31}$ Rome, Antiquario Palatino, inv. 618.
} 


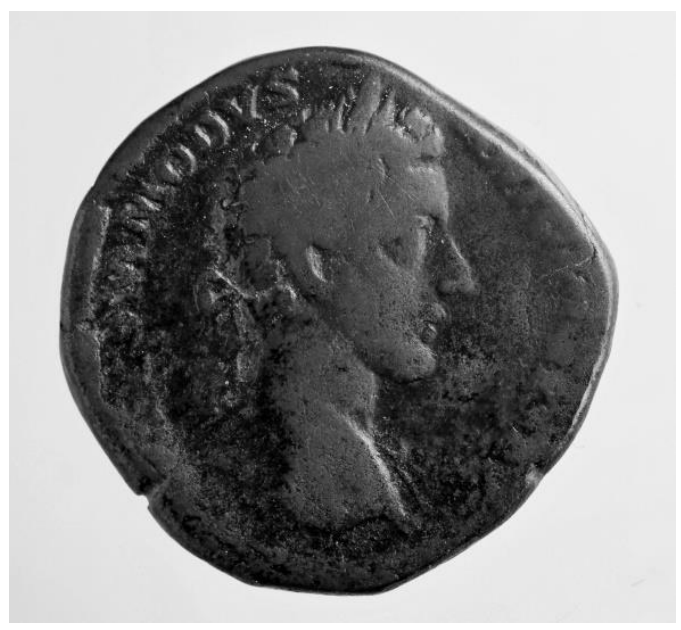

FIG. 15 - Sestertius with the portrait of Commodus, AD 181. Minted in Rome. Oslo, Museum of Cultural history. Photo: Håkon Roland.

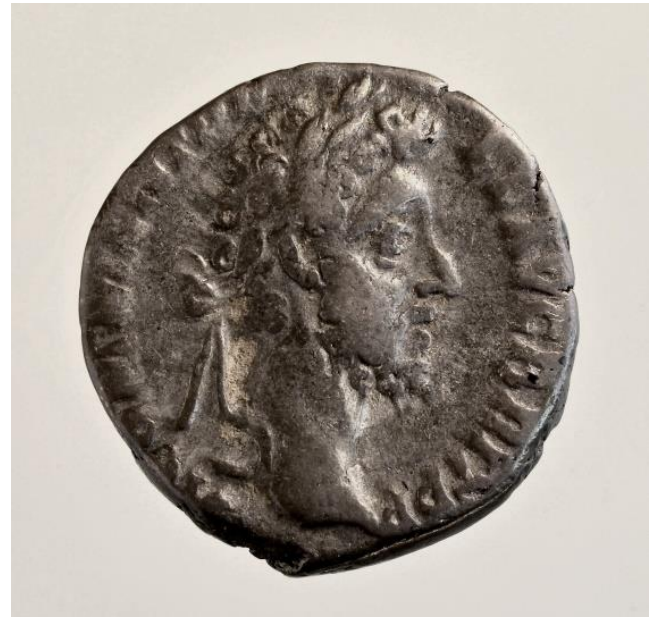

FIG. 16 -Denarius with the portrait of Commodus, AD 190-191. Minted in Rome. Oslo, Museum of Cultural history. Photo: Håkon Roland.

(see FIGS 11 and 14, above). When the bronze colossus is compared to the marble colossus head, the height of the brow differs considerably (see FIGS $1 b$ and $2 b$, above). The low brow of the bronze colossus is clearly visible when seen in profile. Even if the face was dismantled and recast, it would be difficult to alter the size of the forehead, since the other features would also need space. The most convincing interpretation of the face would be that it was detached and remoulded, but that the features, in particular the brow, had to be adjusted to the original proportions.

Reuse from a Julio-Claudian colossal portrait and into that of a Constantinian one would be possible. That portraits of Nero were available for reuse in Late Antiquity is demonstrated by a cameo in Florence, which is recut into a late-antique emperor (Julian?). ${ }^{32}$ The Constantinian emperors were looking back to the Julio-Claudian dynasty, the golden and prosperous age of Augustus, of which Nero was the last emperor. Considering that Nero was subject to damnatio memoriae, it is not likely that a colossal portrait of him had been on display in a public area for two hundred years, but it may have been stored or reused as Commodus in an intermediate version, before it was given its present, Constantinian form. The sun colossus was reused by Commodus, and that may also have been the case with other large-scale sculpture, such as the bronze colossus. ${ }^{33}$

\section{The beard of Commodus}

The profile of Constantine in coin images has probably the best parallel in those of Commodus (FIG. 15 and 16). The noses of Commodus and Constantine have the same downward pointing tip beneath the aquiline shape. The curled sideburns of the Constantinian bronze

\footnotetext{
${ }^{32}$ Megow 2011, 212-213.

${ }^{33}$ Herodian I.15.9; Reg. IV.
} 

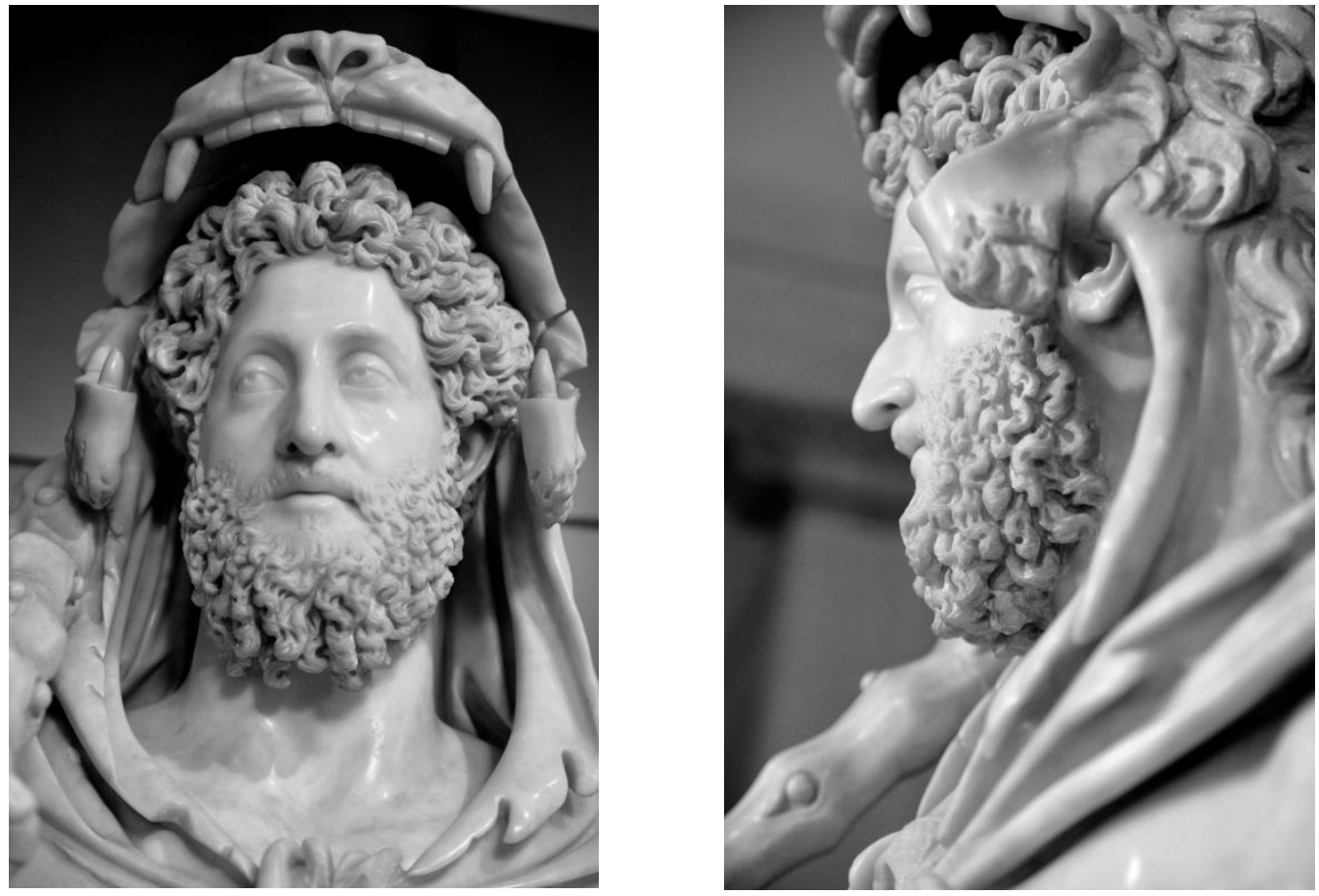

FIGS 17a-b - Commodus as Hercules. Rome, Musei Capitolini, inv. 1120. Photo: author.

colossus are similar to those of Commodus, both in the portraits from before the latter grew a beard, and after, as seen in his coin images. Also in the marble sculpture of Commodus as Hercules in the Capitoline Museum, the sideburns are of a kind which can be compared to those of the bronze colossus (FIG. 17a-b). The similarity between the profile of Commodus in coin images and that of the bronze colossus is striking. It would have been possible to alter the hairstyle of Nero into that of Commodus with a remodelling of the hair above the forehead; a remodelling which is now lost, as the hair above the face was probably recast in Constantinian times. Possibly, the recasting of the edges of the wig was secondary at the time of Constantine. The remoulding of the edges of the different parts of the bronze would have been easier than the recasting of the entire head. The face of the colossus is conventionalized to such an extent that it could well pass from Commodus to Constantine.

In the early representations of Commodus, when he did not wear a beard, an up-dating after the new fashion may have been wanted by this emperor, who was known to be vain. ${ }^{34}$ When Commodus started to wear a beard, one was also attached to the bronze colossus. That explains the indentations and rectangular holes in the bronze. A close-up view on the left cheek reveals indentations where the holes have been cut out. Repairs and rectangular openings have in some places been patched and mended (FIGS 18a-b). An example can be seen in the upper right corner of FIG. 18b. The rectangular cuts may have been made in order to attach a beard, a hypothesis which is founded on the areas in the face where the holes and repa-

\footnotetext{
${ }^{34}$ SHA Comm. 17 informs that he even always made his hair shine of gold.
} 

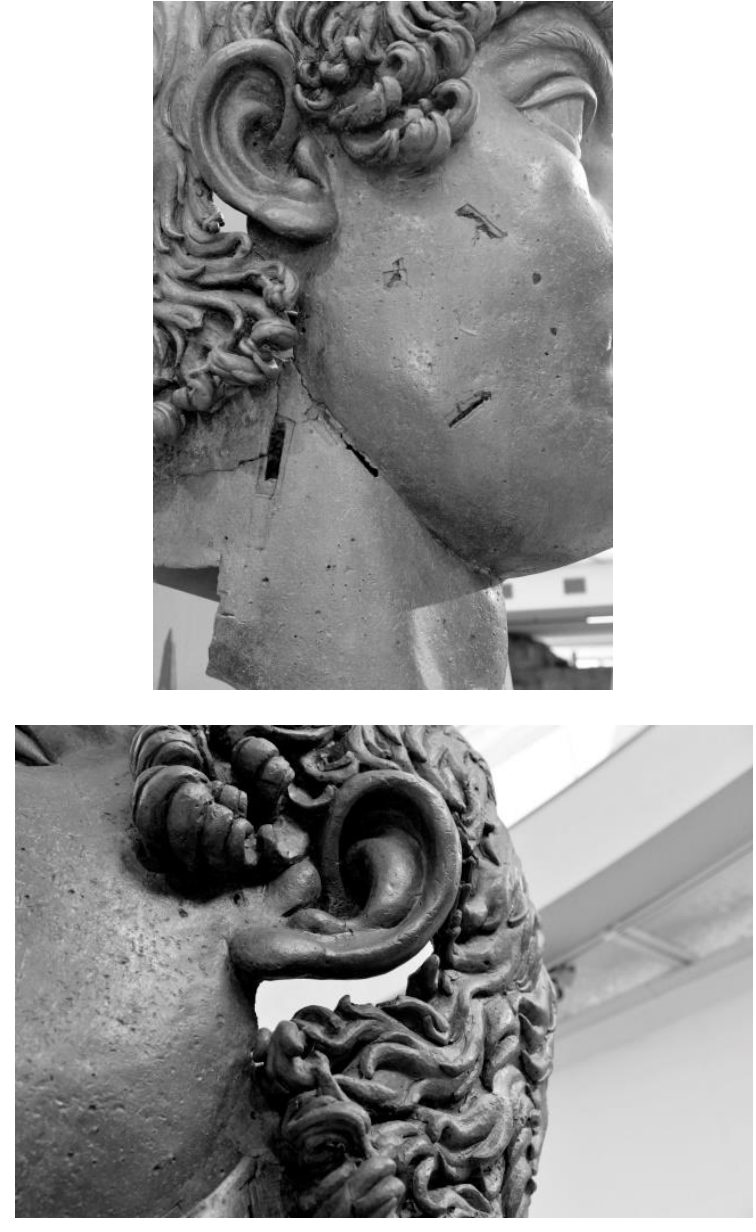

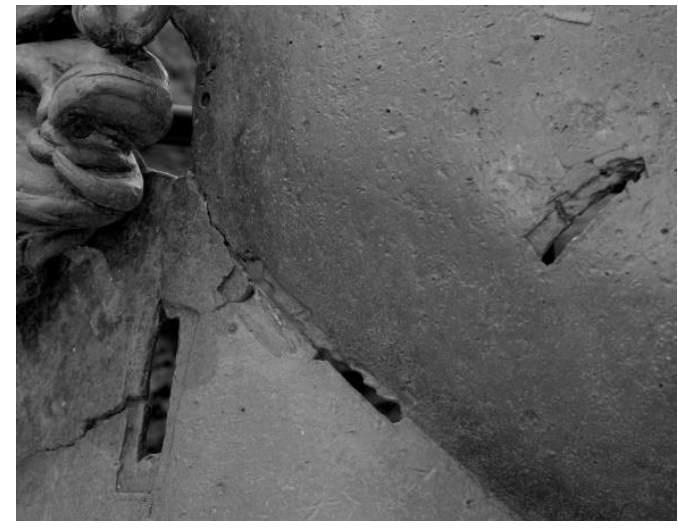

FIGS 18a-b - The Constantinian bronze colossus, detail with reparations and rectangular indentations. Rome, Musei Capitolini, inv. no. 1072. Photo: author.

FIG. 19 - The Constantinian bronze colossus, detail showing the open space between the ears and the face, where a beard could be attached. Rome, Musei Capitolini, inv. no. 1072. Photo: author.

irs have been made. These holes and cuts were not caused by the moulding process, but were secondarily cut into the metal, as cold work. ${ }^{35}$ The uneven edges of the holes testify to that. But first and foremost, the position of the holes in the face of the colossus suggests that the beard of Commodus was secondarily attached. Between the sideburns and the mouth there is a diagonal cut from top left to bottom right. The curly sideburns could be those of Commodus. Beneath, there is a similar cut, running in the opposite direction. Between these, there is a smaller hole, and below that again, where the neck is joined to the jaw, there is a repair, which might be from when the beard was ultimately removed. More interesting in this connection are, however, the large spaces between the ears and the hairstyle, which would be suited for the attachment of a separately moulded beard (FIG. 19). The gap behind the ears has been understood as a consequence of the fact that the two parts - face and back side could not be perfectly fitted, but in my opinion, the openings could be used to attach a beard. Since the hair and beard of Commodus was joined beneath the chin, and did not cover the

\footnotetext{
${ }^{35}$ Confront Fittschen, Zanker 1985, 154.
} 
FIG. 20 - The so-called Dogmatius portrait. Rome, Musei Vaticani, Museo Gregoriano Profano (ex-Lateranese), inv. 725. Photo: Inst. Neg. DAI Röm. Abt. 7271.

upper lip, it would not cause too much of a problem to attach a separately carved beard. The locks of hair closest to the ears seem to have been cut away to give room for something else, such as a separately cast beard.

The reason why there are not similar indentations and rectangular holes on the right handside (as seen from the viewer's perspective) as on the left is probably due to the turn of the head towards left, and the attempt at making the adjustments of the right side as little visible as

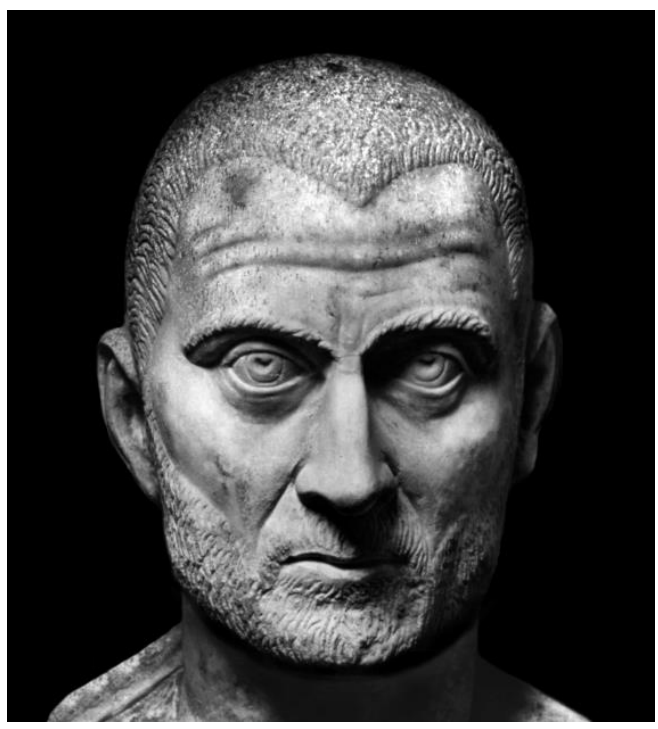
possible. On both sides, the bulk share of the weight has been divided between the spaces behind the ears, but on the left side, there are additional attachments for the support of the beard. Gilding could be used as a way to conceal joints and traces from reuse.

One more aspect, which should be taken into consideration, is the planned sculpture programme of Maxentius. Since Maxentius also identified himself with Hercules, it would have been perfect for him to convert the colossus, which in his time may have looked like Commodus, into himself, as he probably had planned to do with the marble colossus, as argued by Eric Varner. ${ }^{36}$ The bronze colossus may also have been intended for reuse by Maxentius, and was inherited by Constantine, alongside the overall plan for the late-Antique reorganization of Rome. ${ }^{37}$ If the bronze was a part of Maxentius' plan, it would have been easy to remove the beard, and leave the hairstyle as it had been at the time of Nero and Commodus.

When the colossus was reused as Constantine, however, the curly fringe over the brow had to be remoulded, and the curls at the nape of the neck altered. The artists would know how to dismantle the necessary parts, but refrained from doing so where the changes could be undertaken in cold work.

Moreover, the details of the eyes, which seem to have been reworked in cold, strengthen the hypothesis that the face of the colossus would not need to have been entirely recast, but worked in cold with chisel and polishing tools, and perhaps also with paint. The eye apples are round and the irises are indented, and probably remodelled in Late Antiquity, when the painted surface of the original eyes was removed. The carving of the pupils in Late Antiquity may have been undertaken in cold work. Likewise, the diagonal, stitched lines on the eyebrows were probably carved in cold work in Late Antiquity. Fittschen and Zanker convincingly compare them to those of the so-called Dogmatius, which is of marble, and in my opinion recut (FIG. 20). ${ }^{38}$

\footnotetext{
${ }^{36}$ Varner 2004, 287, cat. no. 9.4, figs 209a-d.

${ }^{37}$ For Maxentius as the brain behind Constantine's reorganization of Rome, see for example Marlow 2006.

${ }^{38}$ Fittschen, Zanker 1985, 154. For Dogmatius, see Prusac 2011, 20, 96, 151, cat. no. 377, fig. 94.
} 
The changes, together with re-dedication, would be sufficient in order to give a statue a new identity. Re-dedication was a common practice in Antiquity, especially in the Republican and Early Imperial period, and in Late Antiquity, as for example seen in the statue bases which were re-dedicated to Constantius II at the occasion of his visit to Rome, mentioned above. $^{39}$

\section{Conclusions}

In late-antique Rome, with its plethora of reused portrait statues, the Constantinian bronze colossus would probably stand out as an emblematic expression of Imperial presence. Its function as a memory marker would be one aspect, but still more, perhaps, it functioned as insurance that the emperor, even if far away, was a guarantee for safety and stability.

Most earlier Roman colossi were probably absent, because they had been recast and recut, or were stored in workshops, waiting for the lime kiln or melting-pot. Those which avoided reuse must have played a role in the urban landscape, such as the Constantinian bronze colossus. One possible explanation for its survival may have been that its size made it a challenge to demolish, like the marble colossus of Constantine. Their existence may have made them both valuable to Maxentius, when he planned a new part of Rome in order to celebrate his own glory. As in the case of the marble colossus, he might have wanted to include the bronze colossus in his propaganda programme. But, when Constantine came to power and had the marble colossus reworked into his own image, he may also have claimed the bronze colossus for himself or his offspring.

Assuming that the bronze in the time period prior to Late Antiquity was portraying Commodus, it would at some time have been given the beard of that emperor. The wide openings behind the ears and the rectangular indentations on the cheeks and beneath the chin would have made it possible to attach a separately moulded beard onto the face, without fusing and remoulding. The comparisons to coin images of Commodus are striking. Like Constantine, Commodus had a long, aquiline nose, which ended in a downwards pouting tip.

It can be misleading to compare large-scale and small-scale art, such as colossi and coins, since there will be methodological differences in the production, which lead to varying expressions and styles. Nevertheless, the coin images of Commodus and the Constantinian bronze colossus have resembling profiles, and the face of the first could, with minor alterations made in cold work, pass for that of the other. The brow, however, is lower in the colossus, but that may be explained by the hypothesis that the face - as a mask - originally belonged to Nero, but was entirely remoulded into Commodus. The coin images of Nero show him with an unusually low brow, which would have to be low, even when the portrait was recast into a new individual or it would not fit. The recast face would have to fit into the frame of the coiffure.

The back of the head was not recast, as indicated by the comparison made by Ensoli, as it is still reminiscent of the Julio-Claudian hairstyles. In order to make it look like a Constantinian emperor in the last phase, the edges may have been remoulded into a curly fringe up front and on the back side, at the nape of the neck. It would be possible to detach the front part of the coiffure and have the front edge reshaped. Some of the original curls at the back of the

\footnotetext{
${ }^{39}$ Blanck 1969, passim.
} 
head were cut off, so as to alter the portrait from Commodus into a Constantinian emperor. As the bronze colossus now stands, there is a clear discrepancy between front and backside. The discrepancy is emphasized by the last additions to the colossal portrait, which were made in cold work: the diagonally cut ridges on the eyebrows, and the pupils of the eyes. These additions, the eyebrows in particular, are late-antique.

Nevertheless, the final attribution of the bronze colossus would be difficult to identify. Much has been argued in that matter by others. To the present paper, it is not important whether it showed Constantine or his offspring, as it may first have shown the father, and later the son, by way of rededication. The purpose of this paper has been to suggest, on the basis of the little evidence that exists, that the Constantinian bronze colossus has a complicated past. Like the sun colossus, it may have been going through a recycling process from an effigy of Nero into one of Commodus, and in Late Antiquity, it may have represented a Constantinian emperor. Recycling from the first through the second and to the fourth century would not make it a unique example. Reuse was common in Antiquity. What makes the bronze colossus outstanding is the size, the impressiveness of its golden hue, and its mesmerizing enigma.

\section{Marina Prusac}

Kulturhistorisk museum

University of Oslo

Postboks 6762 St. Olav plass - 0130 Oslo

marinaprusac@gmail.com 


\section{BIBLIOGRAPHY}

Benjamin of Tudela. (12 $2^{\text {th }}$ century; 1907) 1993: The Itinerary of Benjamin of Tudela: Travels in the Middle Ages. trans. Marcus Nathan Adler. Introductions by Michael A. Signer, Marcus Nathan Adler, Asher A., Malibu.

Blanck, H. 1969: Wiederverwendung alter Statuen als Ehrendenkmäler bei Griechen und Römern, Rome.

Castellotti, M.B. 2017: "Il Colosso: trovate le date", Il sole 24 no. 113, 30 April 2017, 38.

Codice topografico 1940-1953: Codice topografico della città di Roma vol. 1-4, eds Valentini, R., Zucchetti, G., Roma.

Delbrueck, R. 1933: Spätantike Kaiserportäts von Constantinus Magnus bis zum Ende des Westreichs, Berlin, Leipzig.

Demandt, A., Engemann, J. 2007: Konstantin der Grosse, Trier.

Ensoli, S. 2000: "Il colosso di bronzo a Roma in età tardoantica: dal Colosso di Nerone al Colosso di Costantino: a proposito dei tre frammenti bronzei dei Musei Capitolini”, in Ensoli, S., La Rocca, E. (eds), Aurea Roma, Roma, 66-90.

Ensoli, S. 2002: "Una nuova ipotesi sul Colosso di Nerone. A proposito dei tre frammenti bronzei dei Musei Capitolini", in Croisille, J.M., Perrin, Y. (eds), Neronia VI. Rome à l'époque néronienne. Institutions et vie politque, économie et société, vie intellectuelle, artistique et spirituelle. Actes du VIe Colloqe international de la SIEN (Rome 19-23 mai 1999), Brussels, 97-122.

Ensoli, S. 2007: "Il Colosso di Nerone-Sol a Roma: una 'falsa' imitazione del Colosso di Helios a Rodi. A proposito della testimonianza di Plino, della ricostruzione del basamento nella valle del Colosseo e dei 'tondi adrianei"', in Perrin, Y. (ed.), Neronia VII. Rome, l'Italie et la Grèce. Hellénisme et philhellénisme au premier siècle après J.-C. Actes du VIIe Coloque international de la SIEN (Athènes, 21-23 octobre 2004), Brussels, 406-427.

Evers, C. 1991: "Remarques sur l'iconographie de Constantine. À propos de remploi de portraits des bons empereurs", MEFRA 103, 785-806.

Fittschen, K., Zanker, P. 1985: Katalog der römischen Porträtts in den Capitolinischen Museen und den anderen kommunalen Sammlungen der stadt Rom 1, Rome.

Humphries, M. 2003: "Roman Senators and Absent Emperors in Late Antiquity”, ActaAArtHist 17, 27-46.
Kähler, H. 1952: “Konstantin 313", JdI 67, 1-30.

Kiilerich, B. 2015: "The Barletta Colossus Revisited: The Methodological Challenges of an Enigmatic Statue", ActaAArtHist 28, 55-72.

Kreikenbom, D. 1992: Griechische und römische Kolossalporträts bis zum ersten Jahrhundert n. Chr. JdI Ergänzungsheft 17.

Liverani, P. 2004: "Reimpiego senza ideologia. La lettura antica degli spolia dall'arco di Costantino all'età carolingia", $R M$ 111, 383-436.

L’Orange, H.P. 1933: Studien zur Geschichte des spätantiken Porträts, Oslo.

L'Orange, H.P., von Gerkan, A. 1939: Der spätantike Bildschmuck des Konstantinsbogens, Berlin.

LSA: Last Statues of Antiquity (online database) http://last statues.classics.ox.ac.uk/

Macchiaroli, G. 1987: Domiziano e Nerva. La statua equestre da Miseno. Una proposta di ricomposizione, Naples.

Marlowe, E. 2006: "Framing the sun: the Arch of Constantine and the late antique cityscape", ArtB 88 no. 2, 223-242.

Megow, W.-R. 2011: "Spätantike Herrscherkameen. Beobachtungen zum konstantinischen 'Klassizismus", ÖIh 80, 167-241.

Parisi Presicce, C. 2006: "Costantino come Giove. Proposta di ricostruzione grafica del colosso acrolitico dalla Basilica Costantiniana”, BCom 107, 127-161.

Prusac, M. 2011: From Face to Face. Recarving of Roman Portraits and the Late-Antique Portrait Arts, Leiden, Boston.

Prusac, M. 2012: "The Arch of Constantine: Continuity and Commemoration through Reuse", ActaAArtHist 25, 127 158.

Ruck, B. 2007: Die Grossen dieser Welt: Kolossalporträts im antiken Rom, Heidelberg.

Varner, E. 2004: Mutilation and transformation. Damnatio memoriae and Roman imperial portraiture, Leiden, Boston.

Varner, E. 2010: "Recutting Roman portraits: problems in interpretation and the new technology in finding possible solutions", MemAmAc 55, 45-56. 